Volume: 2, No. 2 | October 2015

\title{
Transactional Leadership and Job Performance: An Empirical Investigation
}

\author{
Syed Mir Muhammad Shah ${ }^{1}$ \\ University Utara Malaysia and Sukkur Institute of Business Administration, Pakistan
}

Dr. Kamal Bin Ab. Hamid ${ }^{2}$

University Utara Malaysia

\begin{abstract}
Present study investigates the relationship between transactional leadership and job performance in the six large banks of Pakistan. The survey method was used to collect data from the middle managers of six large banks of Pakistan. The data was analyzed and reported using Smart-PLS and its standard reporting style. The findings of the study reveal that transactional leadership has significant relationship with job performance. The last part of the paper presents insights on future research.
\end{abstract}

Keywords: Transactional leadership; Job Performance; Banks; Pakistan.

\section{Introduction}

Job performance has been reported as one of the important factors and significant indicators of organizational performance but it has been conceptualized in different ways (Organ, 1997). (Schmitt \& Chan, 1998) had break up performance into "will do" and "can do". The concept will-do relates to knowledge, skill, ability, and other distinctiveness which one individual needs to carry out a particular job. The can-do creates inspiration for employees to perform the job. Whereas, (Jamal, 2007) defined job performance as an individual's function carrying out efficiently within the prevailing constraints and the resources available. The meaning and scope of job performance varies depending upon job to job. Some researchers including (Campbell, 1990) have comprehended broader scope of performance which can be generalized for various jobs. The scholars have pointed out job performance as a multidimensional concept that consists of task and contextual elements of job performance. However, job performance that contributes to organizational effectiveness has been measured differently and literature reports numerous factors influencing job performance.

Leadership is one of the factors that significantly contribute to job performance (Vigoda-Gadot, 2007; Wang, Law, Hackett, Wang, \& Chen, 2005). Furthermore, the term leadership could be expressed in numerous ways and has been commonly referred to as leadership style (Avolio, 1999). Prominent scholars have suggested https://doi.org/10.30537/sijmb.v2i2.94

1 syedmir@iba-suk.edu.pk

2 abkamal@uum.edu.my 
many different leadership styles and transactional and transformational leadership styles are the most popular among them (Bass, 1985). Particularly, transactional leadership focuses on the achievement of the set goals (Bass, 1985). Additionally, (Humphreys, 2001) explained that transactional leadership is characterized by a reward system for their subordinates that motivate them to meet organizational goals.

Numerous studies suggest that transactional leadership has positive influence on job performance; these studies have been looking into how transactional leadership enhances job performance. Since organizations are unique in terms of their culture and people, hence how do people react towards leadership decision making varies across the globe. Particularly the focus of past studies have been dominantly on the job performance of employees; however the present study aims to address the potential influence of transactional leadership on job performance of the middle managers of six large banks of Pakistan.

\section{Literature Review}

\subsection{Job Performance}

In the research domain of industrial and organizational psychology the job performance has been considered as one of the most important construct (Borman, 2004; Borman \& Motowidlo, 1997; Organ, 1997) In general job, performance refers to effectiveness of individual behaviors that contribute to the organizational objectives (McCloy, Campbell, \& Cudeck, 1994).

Job performance is gauged usually in financial terms, but sometimes other factors are also taken into consideration like task related aspects and expected behaviors, which affect performance (Borman \& Motowidlo, 1993; Britt \& Jex, 2008). Job performance consists of both monetary and non-monetary factors and these are linked with organizational performance and success (Anitha, 2014).

The word "performance" highlights upon the concepts such as "attainment," "accomplishment," and "the execution of a task". Campbell introduced eight factors related to job performance those are; a) job specific proficiency, b) non-job specific task proficiency, c) effort to demonstrate, d) written and oral communication, e) to maintain personal discipline, f) marinating team and peer performance, g) supervision and leadership, $\mathrm{h}$ ) administration and management. He further elaborated that all of these factors are not relevant to all jobs and can be used to portray job performance for any possible occupation. Moreover, all factors and content of factors varies from job to job, primarily each factor is one of motivational elements. The study conducted by (Hochwarter, Kiewitz, Gundlach, \& Stoner, 2004) has further added social worth towards all these factors. Studies report that job performance comprised two dimensions; task performance and organizational citizenship behavior (Borman \& Motowidlo, 1997; Organ, 1988). The importance of task performance and OCB performance is highlighted in the work of (Borman \& Motowidlo, 1993; Motowidlo \& Van Scotter, 1994), according to which these dimensions of measuring job performance play a critical role. 
According to (Motowidlo \& Van Scotter, 1994) and (Campbell, 1990) model provide a comprehensive explanation in terms of defining job performance by further breaking it into task performance and OCB.

\subsection{Transactional Leadership}

The transactional leadership emphasizes on the need recognition of the followers and it clarifies the ways in terms of how these needs are to be fulfilled with a mere objective of enhancing job performance for attaining desired objectives. It is comprised of contingent reward and management-by-exception (Bass \& Avolio, 2000).This style of leadership is comprised of behavior of an exchange in between the leader and follower, where rewards are always linked with the effort and output produced by the subordinate (Burns, 1978). (Bass, 1985) has mentioned two types of behaviors of transactional leadership styles; contingent reward and management by exception. Contingent behavior is related to positive feedback by the supervisor. This type of behavior is related to criticism and negative feedback by the leader subject to unsatisfactory performance by the subordinate. The risk of punishment makes a transactional conduct which differentiates this from "arbitrary and punitive behavior" (Kohli, 1985).

Transactional leaders make their subordinates happy by rewarding them with the best possible way of identifying their desires (Wegner, 2004). Transactional leader is concerned with a stable environment and with less competition (Tichy \& Devanna, 1986). According to (Zaleznik, 1977) transactional leaders are those who set goals for their followers; allocate tasks and get the work done; finally reward those followers who perform better and punish those who do not perform. In the organizational behavior studies, they have widely used the type of transactional leadership style as effective style which can motivate the followers to enhancing their inspiration to achieve the objectives of the organization. (Burns, 1978) as a pioneer to the study on transactional leadership pointed out those transactional leaders are motivating their followers through appealing them to their self interests. The theories of transactional leadership are based on the idea that leader-follower relationships are based on a number of exchanges or implicit bargain between them. Transactional leadership is characterized by behaviors and attitudes that emphasize the quality of exchanges between superiors and subordinates. According to (Bass \& Stogdill, 1990) the achievement of tasks and goals are the responsibilities of the leaders who are the main actors to motivate the followers in identifying the objectives and developing confidence to meet the desired high performance levels.

\subsection{Transactional Leadership and Job Performance}

The relationship between leadership and job performance has received considerable scholarly attention. Most of the studies on the relationship between transformational / transactional leadership and job performance have yielded both significant as well as insignificant results. According to (Bass, 1985), transactional, transformational, and laissez-faire leadership style plays an important role in management. Additionally, this study also reports a high correlation between job performance and transactional leadership using Multifactor Leadership Questionnaire (MLQ). 
According to (McGrath \& MacMillan, 2000), the effective leadership styles contribute towards better performance in the times when new challenges are faced; this notion of the positive relationship between transactional leadership and job performance is also supported by (Gumusluoglu \& Ilsev, 2009; Mahdinezhad, Suandi, bin Silong, \& Omar, 2013; Zhu, Chew, \& Spangler, 2005). A strong relationship is evident in most studies about the relationship between performance of the organization and its managerial leadership. Leadership is critical at all levels in an organization. However, the managerial level embraces high significance. In many organizations, it seems that leadership is one of the most effective processes in influencing employees to drive best out of them. (Rickards \& Moger, 2006) stated that leaders of the organization have the ability to educate as well as support their employees while challenging them with creative and innovative work at the same time. Leaders hence, with their words, actions and behavior encourage the employees to put extra effort to promote achievement of set aim and goals. On the contrary, other studies report a negative relationship between transactional leadership and job performance (Geyer \& Steyrer, 1998; Lowe, Kroeck, \& Sivasubramaniam, 1996; MacKenzie, Podsakoff, \& Rich, 2001; Parry \& Proctor-Thomson, 2002).

Hence the relationship between transactional leadership and job performance still stands confusing and the results evident a mixed relationship between the two. The present study, in the light of leader member exchange (LMX) theory (Graen, 1976), aims at investigating the postulated relationship between transactional leadership and job performance in the banking sector of Pakistan.

\section{Methodology}

\subsection{Sample and Population}

The Full time branch managers of six large banks of Pakistan were surveyed. For the total population of 1314 (Pakistan Banks Association, 2014) branch managers all around the province of Sindh a minimum of 302 (Krejcie \& Morgan, 1970), responses were required. Hence using proportionate random sampling a total of 500 questionnaires were mailed to the bank branches with self-addressed returned envelops out of which 297 useable questionnaires were received.

\subsection{Measures}

The job performance was measured using job performance scale developed by (Williams \& Anderson, 1991) with 37 items and Transactional leadership was measured using Multifactor Leadership Questionnaire (MLQ) developed by (Bass \& Avolio, 2000) with 12 items.

Respondents were asked to self evaluate about perceived job performance and transactional leadership style. The five point Likert scale with 1 indicating (strongly disagree) and 5 as (strongly agree) was employed.

\subsection{Demographic Profile of the respondents}

The majority of managers were fall in 31 to 40 years of age group with $39.1 \%$ and lowest percent falls in 51 or above age group that is with 8.1 percent. The majority of 
the managers were male with $94.9 \%$ whereas females are $4.7 \%$ percentage only. $84.2 \%$ managers are married and $15.8 \%$ are unmarried. A larger portion of mangers were graduates with $91.2 \%$, undergraduate. The major two groups of the managers have salaries PKR 40,000 or less with $21.5 \%$ and PKR 80,000 or above with $21.2 \%$. The detailed demographics of the respondents are given in the table 1 below:

Table 1: Demographic Profile of Respondents

\begin{tabular}{|c|c|c|}
\hline Characteristics & Frequency & Percentage \\
\hline $\begin{array}{l}\text { Gender } \\
\text { Male } \\
\text { Female } \\
\text { Age }\end{array}$ & $\begin{array}{l}282 \\
14\end{array}$ & $\begin{array}{l}94.9 \\
4.7\end{array}$ \\
\hline $20-30$ years & 74 & 24.9 \\
\hline $31-40$ years & 116 & 39.1 \\
\hline $41-50$ years & 82 & 27.6 \\
\hline 51 and above & 24 & 8.1 \\
\hline \multicolumn{3}{|l|}{ Position } \\
\hline Branch Manager & 155 & 52.2 \\
\hline Operations Manager & 141 & 47.5 \\
\hline \multicolumn{3}{|l|}{ Experience } \\
\hline Less than five years & 46 & 15.5 \\
\hline 5 to less than 10 years & 117 & 39.4 \\
\hline 10 to Less than 15 & 49 & 16.5 \\
\hline 15 to less than 20 & 32 & 10.8 \\
\hline 20 to less than 25 & 17 & 5.7 \\
\hline 25 to less than 30 & 15 & 5.1 \\
\hline 30 and above & 21 & 7.1 \\
\hline \multicolumn{3}{|l|}{ Qualification } \\
\hline Undergraduate & 22 & 7.4 \\
\hline Graduate & 271 & 91.2 \\
\hline
\end{tabular}




\begin{tabular}{lll} 
Mir M. Shah \& Kamal Bin. Hamid/ Transactional Leadership and Job Performance: An Empirical Investigation \\
\hline Post Graduate & 4 & 1.3 \\
Monthly Income & 64 & 21.5 \\
$40 \mathrm{~K}$ or less & 56 & 18.9 \\
41 to $50 \mathrm{~K}$ & 51 & 17.2 \\
51 to $60 \mathrm{~K}$ & 33 & 11.1 \\
61 to $70 \mathrm{~K}$ & 30 & 10.1 \\
71 to $80 \mathrm{~K}$ & 63 & 21.2 \\
81 to above & & 84.2 \\
Marital Status & 250 & 15.8 \\
Married & 47 & \\
Unmarried & &
\end{tabular}

\section{Analysis and Results}

Before performing the analysis, the assumptions related to linearity, normality and multi-co-linearity were assessed (Hair, Ringle, \& Sarstedt, 2011; Tabachnick \& Fidell, 2001). After satisfying these assumptions, the partial least square (PLS) path modeling (Wold, 1974, 1985) using Smart PLS 2.0 (Ringle, Wende, \& Will, 2005).

\subsection{Measurement Model Results}

The individual item reliability, internal consistency reliability and discriminant validity were ensured for assessing the psychometric properties of the scales that have been adopted in the present study. In order to determine individual item reliability the outer loadings were used following on (Hair Jr, Hult, Ringle, \& Sarstedt, 2013).

Table 2 a: Results of Measurement Model

\begin{tabular}{llllll}
\hline$\underline{\text { Latent Variables }}$ & $\underline{\text { Items }}$ & & $\underline{\text { Loadings }}$ & $\underline{\text { AVE }}$ & $\underline{\text { CR }}$ \\
\hline Contingent Reward (CR) & LS1 & 0.76434 & 0.619921 & 0.765223 \\
& LS31 & 0.809708 & & \\
Management by Exception & -Active & LS22 & 0.824517 & 0.632942 & 0.774977 \\
\hline
\end{tabular}


(MBEA)

LS25 $\quad 0.765543$

Management by Exception -Passive $\quad$ LS10 $\quad 0.815171 \quad 0.51476 \quad 0.807711$ (MBEP)

LS15 $\quad 0.612149$

LS18 $\quad 0.723341$

LS3 $\quad 0.704689$

Task-Performance

JPTSK1 $\quad 0.83753 \quad 0.568512 \quad 0.793924$

JPTSK2 0.820655

JPTSK3 0.574981

Organizational Citizenship Behavior JPOCB28 $0.634294 \quad 0.507909 \quad 0.877523$ (OCB)

JPOCB32 0.642152

JPOCB33 0.790144

JPOCB34 0.758635

JPOCB35 0.774777

JPOCB36 0.634145

JPOCB37 0.733758 
Table 2 b: Correlation and Discriminate Validity

\begin{tabular}{llllll}
\hline & $\underline{\mathbf{1}}$ & $\underline{\mathbf{2}}$ & $\underline{\mathbf{3}}$ & $\underline{\mathbf{4}}$ & $\underline{\mathbf{5}}$ \\
\hline CR & $\mathbf{0 . 7 8 7 3 5 0 6}$ & & & & \\
MBEA & 0.190901 & $\mathbf{0 . 7 9 5 5 7 6 5}$ & & & \\
& & & & & \\
MBEP & 0.056968 & 0.288594 & $\mathbf{0 . 7 1 7 4 6 7 8}$ & & \\
& & & & & \\
OCB & 0.284067 & 0.35446 & 0.185216 & $\mathbf{0 . 7 1 2 6 7 7 3}$ & \\
Task & 0.279529 & 0.147699 & 0.011416 & 0.298467 & $\mathbf{0 . 7 5 3 9 9 7 3}$ \\
\hline
\end{tabular}

Note: bold diagonal figures are the square root of $A V E$.

The items which consisted of 0.5 and above loadings were retained (Barclay, Higgins, \& Thompson, 1995; Chin, 1998). The loadings are presented in Table 1.Further, in order to ascertain internal consistency reliability the composite reliability coefficient were used which according to (Bagozzi \& Yi, 1988) and (Hair et al., 2011) should be at least 0.7 or above (refer table 1). Therefore, it can be said that the present study meets the internal consistency reliability.

The average variance extracted (AVE) was used for determining discriminant validity drawing on the suggestions of (Fornell \& Bookstein, 1982). According to whom the square root of AVE should be greater than the correlations among latent variables. The results of discriminant validity are presented in Table 2 .

\subsection{Structure and Model Results}

In order to assess the significance of the path coefficients the bootstrapping procedure was used with 5000 bootstraps and 297 cases (Hair, Sarstedt, Ringle, \& Mena, 2012). The path coefficients are presented in Table 3 and Figure 1.

Table 3: Path Coefficients and Hypothesis testing

\begin{tabular}{|c|c|c|c|c|c|c|}
\hline Hypothesis & & Relationship & Beta & $\underline{\mathrm{SE}}$ & t- & Decision \\
\hline & $\mathrm{H} 1$ & $\begin{array}{l}\text { Transactional -> } \\
\text { Job- } \\
\text { Performance }\end{array}$ & 0.084075 & 0.044026 & 1.909667 & Supported \\
\hline
\end{tabular}

Note: Transactional $=$ Transactional Leadership 
Figure 1: Assessment of structure model

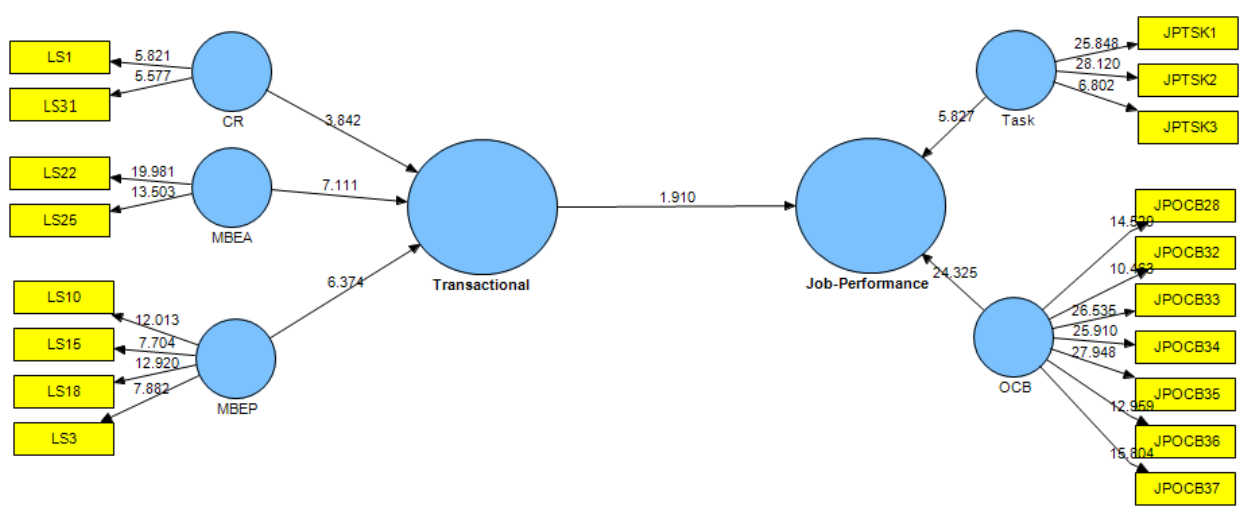

The relationship between transactional leadership and job performance is discussed in Table 3. According to which the path coefficient from transactional leadership to job performance is 0.08 (t-value $=1.90)$. Hence it suggests that there is a relationship between transactional leadership and job performance. Table 4 presents the r-square value of job performance which is 0.87 . This informs us that the transactional leadership explains 87 percent of the variance in the job performance.

Table 4: Variance Explained in the Endogenous Variable

\begin{tabular}{ll}
\hline Latent Variable & Variance Explained \\
\hline Job Performance & $87 \%$ \\
\hline
\end{tabular}

\section{Discussion, Recommendations and Conclusion}

The purpose of the present study was to assess the transactional leadership and job performance relationship. The results of the study suggest that transactional leadership has positive relationship with job performance. These results are also consistent with the previous research (Dolatabadi \& Safa, 2010; Mohammad Mosadegh Rad \& Hossein Yarmohammadian, 2006; Voon, Lo, Ngui, \& Ayob, 2011).

In the light of Leader Member Exchange (LXM) theory (Graen, 1976), this study provides empirical evidence that transactional leadership adds positively to the increase of employees job performance. It posits that transactional leadership style is perceived to be very critical factor that influences employee's job performance. The results of the present study suggest that leaders by adopting transactional style could influence dramatically job performance of employees. Therefore, prominent leaders should consider this style of management.

The present study addresses the examination of transactional leadership with job performance among the branch managers of big six banks of Pakistan. Drawing upon LXM theory the results suggest a positive association between the two. Hence it is suggested to broaden the scope of this study into the other banks of the country to better explain this relationship and collect further evidence to validate these results. 
Besides, only transactional leadership style was investigated under this study. Therefore, it is also suggested to investigate the influence of other potential leadership styles over job performance in this industry. This study might also have limitations particularly due to its cross-sectional design. Further analysis on longitudinal basis is suggested.

Although the present study has several limitations despite that it reports a positive relationship between transactional leadership style and job performance. Thus, it can be concluded that leaders opting transactional style can potentially contribute to the employee's job performance and ultimately increasing organizational effectiveness.

\section{References}

Anitha, J. (2014). Determinants of employee engagement and their impact on employee performance. International Journal of Productivity and Performance Management.

Avolio, B. J. (1999). Full leadership development: Building the vital forces in organizations: Sage.

Bagozzi, R. P., \& Yi, Y. (1988). On the evaluation of structural equation models. Journal of the academy of Marketing Science, 16(1), 74-94.

Barclay, D., Higgins, C., \& Thompson, R. (1995). The partial least squares (PLS) approach to causal modeling: Personal computer adoption and use as an illustration. Technology studies, 2(2), 285-309.

Bass, B. M. (1985). Leadership and performance beyond expectations: Free Press; Collier Macmillan.

Bass, B. M., \& Avolio, B. J. (2000). MLQ: Multifactor leadership questionnaire: Mind Garden.

Bass, B. M., \& Stogdill, R. M. (1990). Bass \& Stogdill's handbook of leadership: Theory, research, and managerial applications: Simon and Schuster.

Borman, W. C. (2004). The concept of organizational citizenship. Current directions in psychological science, 13(6), 238-241.

Borman, W. C., \& Motowidlo, S. (1993). Expanding the criterion domain to include elements of contextual performance. Personnel Selection in Organizations; San Francisco: Jossey-Bass, 71.

Borman, W. C., \& Motowidlo, S. J. (1997). Task performance and contextual performance: The meaning for personnel selection research. Human performance, 10(2), 99-109.

Britt, T. W., \& Jex, S. (2008). Organizational psychology: A scientist-practitioner approach: New York, NY: Wiley.

Burns, J. M. (1978). Leadership New York. NY: Harper and Row Publishers.

Campbell, J. P. (1990). The role of theory in industrial and organizational psychology.

Chin, W. W. (1998). The partial least squares approach to structural equation modeling. Modern methods for business research, 295(2), 295-336.

Dolatabadi, H. R., \& Safa, M. (2010). The effect of directive and participative leadership style on employees' commitment to service quality. International Bulletin of Business Administration(9), 31-42. 
Fornell, C., \& Bookstein, F. L. (1982). Two structural equation models: LISREL and PLS applied to consumer exit-voice theory. Journal of Marketing Research, 440-452.

Geyer, A., \& Steyrer, J. (1998). Messung und Erfolgswirksamkeit transformationaler Führung. Zeitschrift für Personalforschung/German Journal of Research in Human Resource Management, 377-401.

Graen, G. (1976). Role-making processes within complex organizations. Handbook of industrial and organizational psychology, 1201, 1245.

Gumusluoglu, L., \& Ilsev, A. (2009). Transformational leadership, creativity, and organizational innovation. Journal of business research, 62(4), 461-473.

Hair, J. F., Ringle, C. M., \& Sarstedt, M. (2011). PLS-SEM: Indeed a silver bullet. Journal of Marketing Theory and Practice, 19(2), 139-152.

Hair, J. F., Sarstedt, M., Ringle, C. M., \& Mena, J. A. (2012). An assessment of the use of partial least squares structural equation modeling in marketing research. Journal of the academy of Marketing Science, 40(3), 414-433.

Hair Jr, J. F., Hult, G. T. M., Ringle, C., \& Sarstedt, M. (2013). A primer on partial least squares structural equation modeling (PLS-SEM): Sage Publications.

Hochwarter, W. A., Kiewitz, C., Gundlach, M. J., \& Stoner, J. (2004). The impact of vocational and social efficacy on job performance and career satisfaction. Journal of Leadership \& Organizational Studies, 10(3), 27-40.

Humphreys, J. H. (2001). Transformational and transactional leader behavior: The relationship with support for e-commerce and emerging technology. Journal of Management Research, 1(3), 149.

Jamal, M. (2007). Job stress and job performance controversy revisited: An empirical examination in two countries. International journal of stress management, 14(2), 175 .

Kohli, A. K. (1985). Some unexplored supervisory behaviors and their influence on salespeople's role clarity, specific self-esteem, job satisfaction, and motivation. Journal of Marketing Research, 424-433.

Krejcie, R. V., \& Morgan, D. W. (1970). Determining sample size for research activities. Educ Psychol Meas.

Lowe, K. B., Kroeck, K. G., \& Sivasubramaniam, N. (1996). Effectiveness correlates of transformational and transactional leadership: A meta-analytic review of the MLQ literature. The Leadership Quarterly, 7(3), 385-425.

MacKenzie, S. B., Podsakoff, P. M., \& Rich, G. A. (2001). Transformational and transactional leadership and salesperson performance. Journal of the academy of Marketing Science, 29(2), 115-134.

Mahdinezhad, M., Suandi, T. B., bin Silong, A. D., \& Omar, Z. B. (2013). Transformational, transactional leadership styles and job performance of academic leaders. International Education Studies, 6(11), p29.

McCloy, R. A., Campbell, J. P., \& Cudeck, R. (1994). A confirmatory test of a model of performance determinants. Journal of applied psychology, 79(4), 493.

McGrath, R. G., \& MacMillan, I. C. (2000). The entrepreneurial mindset: Strategies for continuously creating opportunity in an age of uncertainty (Vol. 284): Harvard Business Press.

SIJMB $\quad P$ - ISSN: 2313-1217 E-ISSN: 2410-1885 @ 2015 Sukkur Institute of Business Administration $\quad$ V.2, No.2|Oct 15 
Mohammad Mosadegh Rad, A., \& Hossein Yarmohammadian, M. (2006). A study of relationship between managers' leadership style and employees' job satisfaction. Leadership in Health Services, 19(2), 11-28.

Motowidlo, S. J., \& Van Scotter, J. R. (1994). Evidence that task performance should be distinguished from contextual performance. Journal of applied psychology, 79(4), 475.

Organ, D. W. (1988). Organizational citizenship behavior: The good soldier syndrome: Lexington Books/DC Heath and Com.

Organ, D. W. (1997). Organizational citizenship behavior: It's construct clean-up time. Human performance, 10(2), 85-97.

Parry, K., \& Proctor-Thomson, S. (2002). Leadership, culture and performance: The case of the New Zealand public sector. Journal of Change Management, 3(4), 376-399.

Rickards, T., \& Moger, S. (2006). Creative leaders: a decade of contributions from Creativity and Innovation Management Journal. Creativity and Innovation Management, 15(1), 4-18.

Ringle, C. M., Wende, S., \& Will, A. (2005). SmartPLS 2.0 (beta): Hamburg.

Schmitt, N., \& Chan, D. (1998). Personnel selection: A theoretical approach: Sage.

Tabachnick, B. G., \& Fidell, L. S. (2001). Using multivariate statistics.

Tichy, N. M., \& Devanna, M. A. (1986). The transformational leader. Training \& Development Journal.

Vigoda-Gadot, E. (2007). Leadership style, organizational politics, and employees' performance: An empirical examination of two competing models. Personnel Review, 36(5), 661-683.

Voon, M. L., Lo, M. C., Ngui, K. S., \& Ayob, N. B. (2011). The influence of leadership styles on employees' job satisfaction in public sector organizations in Malaysia. International Journal of Business, Management and Social Sciences, 2(1), 24-32.

Wang, H., Law, K. S., Hackett, R. D., Wang, D., \& Chen, Z. X. (2005). Leadermember exchange as a mediator of the relationship between transformational leadership and followers' performance and organizational citizenship behavior. Academy of management Journal, 48(3), 420-432.

Wegner, L. (2004). Organizational leaders and empowered employees: The relationship between leadership styles, perception of styles, and the impact on organizational outcomes. Capella University. From ProQuest database.

Williams, L. J., \& Anderson, S. E. (1991). Job satisfaction and organizational commitment as predictors of organizational citizenship and in-role behaviors. Journal of Management, 17(3), 601-617.

Zaleznik, A. (1977). Managers and leaders: Are they different. Harvard business, 55(May-June), 67-78.

Zhu, W., Chew, I. K., \& Spangler, W. D. (2005). CEO transformational leadership and organizational outcomes: The mediating role of human-capital-enhancing human resource management. The Leadership Quarterly, 16(1), 39-52. 